\title{
Qualitative postural analysis among boys and girls of seven to ten years of age
}

\author{
Análise postural qualitativa entre meninos e meninas de sete a dez anos de idade
}

Penha PJ, Casarotto RA, Sacco ICN, Marques AP, João SMA

\begin{abstract}
Background: Postural abnormalities are often found in children. At this stage of life, posture undergoes many adjustments and adaptations due to body changes. Objective: To qualitatively identify the postural abnormalities which occur most frequently among children aged seven and ten years, comparing boys and girls, and to evaluate these subjects' lumbar flexibility. Methods: One hundred and ninetyone children were photographed in the sagittal and frontal planes. The variables analyzed were: ankle (valgus and varus), tibiotarsal angle (opened and closed), knee (hyperextension and semiflexion, valgus and varus), pelvis (anteversion and retroversion; lateral pelvic inclination), trunk (antepulsion and retropulsion), lumbar spine (hyperlordosis and rectification), thoracic spine (hyperkyphosis and rectification), cervical spine (hyperlordosis and rectification), scoliosis, shoulder (imbalance and protraction), scapula (winged, abducted and adducted) and head (tilt and protraction). The lumbar flexibility was assessed using Schöber's index. Results: The boys had greater incidence of winged scapula, shoulder imbalance, protraction of shoulders and head and cervical hyperlordosis than the girls did. Conversely, the girls had greater incidence of head tilt and larger Schöber index values. Conclusions: There were abnormalities in children's postural development that are probably related to muscle, skeletal and flexibility differences between the genders. These differences may influence each child's postural pattern during growth.

Article registered in the Australian New Zealand Clinical Trials Registry (ANZCTR) under the number 12607000573459.
\end{abstract}

Key words: posture; evaluation; child; physical therapy (specialty); gender.

\section{Resumo}

Contextualização: Alterações posturais são freqüentemente encontradas em crianças. Nessa fase, a postura sofre uma série de ajustes e adaptações às mudanças no próprio corpo. Objetivo: Identificar, de maneira qualitativa, quais as alterações posturais mais freqüentes em crianças entre sete e dez anos, comparando meninos e meninas, e avaliar a flexibilidade lombar desses sujeitos. Materiais e métodos: Cento e noventa e uma crianças foram fotografadas nos planos frontal e sagital. As variáveis analisadas foram: tornozelo (valgo e varo), ângulo tíbio-társico (aberto e fechado), joelho (hiperextensão e semiflexão, valgo e varo), pelve (anteversão e retroversão, inclinação pélvica lateral), tronco (antepulsão e retropulsão), lombar (hiperlordose e retificação), torácica (hipercifose e retificação), cervical (hiperlordose e retificação), escoliose, ombro (desnível e protração), escápula (alada, abduzida e aduzida) e cabeça (inclinada e protraída). A flexibilidade da coluna lombar foi avaliada pelo índice de Schöber. Resultados: Os meninos mostraram maior incidência de escápula alada, desnível de ombros, protração de ombros e cabeça e hiperlordose cervical do que as meninas. Por sua vez, as meninas apresentaram maior incidência de inclinação de cabeça e maior valor para o índice de Schöber. Conclusões: Existem alterações no desenvolvimento postural das crianças que podem estar relacionadas a diferenças, entre os sexos, no sistema muscular, esquelético e na flexibilidade. Estas diferenças podem influenciar o padrão postural do indivíduo durante o crescimento. Artigo registrado na Australian New Zealand Clinical trials Registry (ANZCTR) sob o número 12607000573459.

Palavras-chave: postura; avaliação; criança; fisioterapia (especialidade); gênero.

Received: 20/11/2007 - Revised: 01/05/2008 - Accepted: 07/07/2008 


\section{Introduction $: \therefore$.}

Posture can be defined as the position of all the body segments observed at a specific moment ${ }^{1}$. Adequate posture occurs when the body is kept in balance with the least expenditure of energy possible ${ }^{2}$. Inadequate posture consists of poor interrelations between parts of the body ${ }^{2}$. These imperfect interrelations cause muscle tension and shortening, which makes appropriate joint movements more difficult to achieve ${ }^{3,4}$. Incorrect movements cause injuries to the musculoskeletal system ${ }^{5,6}$ and limit the ability to perform daily activities. The prevalence of postural problems is associated with pain ${ }^{5,6}$.

There are intrinsic and extrinsic factors that can influence a child's posture, such as heredity, environment or physical conditions under which the child lives, level of physical activity, socioeconomic level, emotional factors and physiological abnormalities due to human growth and development ${ }^{3,7-13}$. Furthermore, postural responses to daily demands differ according to gender and the individual's skeletal maturity ${ }^{3,8,14}$.

The prepubertal phase and puberty are periods of life when posture undergoes many adjustments and adaptations due to changes in the body. From seven to 12 years of age, human posture undergoes major transformations to balance the new body proportions ${ }^{3}$. These changes in body proportions may be due to differences in bone and muscle tissue growth rates ${ }^{3}$. It is important to diagnose postural deviations between the ages of seven and 14 years, not only because the child is susceptible to modifications of the bone system but also because poor bone formation and poor posture are more easily corrected at this stage of development. It has been reported that improper postures adopted by children at home and at school cause body musculature imbalances that result in postural abnormalities ${ }^{7-9,15,16}$. These changes, if not corrected, may last throughout adult life and cause painful syndromes ${ }^{7,915}$.

In a previous study, we assessed 132 girls aged seven to ten years ${ }^{17}$. The results showed incidences of more than $50 \%$ for the following postural abnormalities: genu valgum (knock knees), medial rotation of hip, antepulsion, pelvic anteversion, knee hyperextension, lumbar hyperlordosis, valgus ankle, shoulder imbalance, lateral pelvic inclination, trunk rotation, winged scapula, medial rotation of shoulders and head tilt. Deviations such as scoliosis and thoracic hyperkyphosis had incidences of less than $40 \%$ in girls aged seven to eight years. From these results, it was concluded that some postural abnormalities reflect normal postural development, and are corrected by the child's growth. On the other hand, other abnormalities consist of asymmetries that can be caused by the daily demands on the body, and these may have a negative impact on the quality of life during childhood and adulthood.

Postural assessment methods can be classified as quantitative or qualitative. Quantitative procedures using X-rays are effective but expensive, while most devices only assess a small number of postural deviations and risk exposing the subject to the harmful effects of radiation. Other quantitative methods, such as the Wickens-Kiphuth procedure and the procedure described by Arnheim, Auxter, Crowe ${ }^{18}$, require longer preparation times for participants and no indications of the reliability of these techniques have been shown ${ }^{19}$. However, qualitative methods such as visual assessment of posture using photographs are inexpensive, practical and effective for screening populations, with regard to showing the relationship between posture and health ${ }^{19}$. Watson and Mac Donncha ${ }^{19}$ developed a qualitative scale to assess ten different postural characteristics and found that their scale had high degrees of inter and intra-rater reliability at different times. Therefore, measuring the reliability of the qualitative postural assessment is important in order to verify that the results are consistent and reproducible ${ }^{20}$.

Considering the lack of information on postural development among children and the existence of gender-specific differences in relation to some postural abnormalities observed in adults $^{21}$, the objective of this study was to identify qualitatively which postural abnormalities occur more often among schoolage children aged seven to ten years, and to compare the incidence of abnormalities between boys and girls.

\section{Materials and methods :::}

\section{Sample}

This project assessed 77 boys and 114 girls aged seven to ten years, thus totaling a sample of 191 subjects (Table 1). The children were randomly selected from a public institution,

Table 1. Number of children assessed by age and gender.

\begin{tabular}{lccccc}
\hline & $\begin{array}{c}7 \text { years old } \\
\text { (6 years and } 9 \\
\text { months to 7 years } \\
\text { and 8 months) }\end{array}$ & $\begin{array}{c}\text { 8 years old } \\
\text { (7 years and } 9 \\
\text { months to 8 years } \\
\text { and 8 months) }\end{array}$ & $\begin{array}{c}\text { 9 years old } \\
\text { (8 years and } 9 \\
\text { months to 9 years } \\
\text { and 8 months) }\end{array}$ & $\begin{array}{c}\text { 10 years old } \\
\text { (9 years and 9 } \\
\text { months to 10 years } \\
\text { and 8 months) }\end{array}$ \\
\hline Boys & 20 & 20 & 16 & 21 & 77 \\
\hline Girls & 32 & 31 & 27 & 24 & 114 \\
\hline Total & 52 & 51 & 43 & 45 \\
\hline
\end{tabular}


Clorinda Danti State Elementary School, in São Paulo, SP, Brazil. Children were excluded from the sample if they presented any neuromuscular, traumatic and/or respiratory pathological conditions and, for the girls, if they had already reached the menarche ${ }^{3}$. All the evaluations were carried out at the Clorinda Danti State Elementary School, in the same classroom, and all the students were assessed on a single day.

\section{Procedures}

The students' parents were notified about the project by means of a letter supplying information about the postural examination. For their children to be included, they were asked to sign and return an informed consent form. The project had previously been granted approval by CAPPesq, at the Clinical Hospital of the School of Medicine, Universidade de São Paulo (Protocol number: 036/03).

The postural assessment was based on photos of the students that were taken with the students in orthostatic posture, in the sagittal and frontal planes. The reference points of Kendall, McCreary, Provance ${ }^{22}$ were used as the normal parameters. The following bone reference points were marked out on each student: lateral malleoli; head of the fibulae; greater trochanter of the femur, anterior superior and posterior superior iliac spines; coracoid process; cervical (C5 and C7), thoracic (T2 and T7), lumbar (L1 and L5) and sacral (S1) spinous processes; and inferior angle of the scapula.

The abnormalities were assessed in terms of the following non-dichotomous variables: ankle (aligned, valgus or varus); tibiotarsal angle (aligned, opened or closed); knee in frontal plane (aligned, knock-knee or bowleg); knee in sagittal plane (aligned, hyperextension or semiflexion); pelvis (aligned, anteversion or retroversion); trunk (aligned, antepulsion or retropulsion); lumbar (aligned, hyperlordosis or rectification); thoracic (aligned, hyperkyphosis or rectification); scapula (aligned, abducted or adducted) and cervical (aligned, hyperlordosis or rectification); and the following dichotomous variables: pelvis (aligned or lateral pelvic inclination); scoliosis (present or absent); scapula (aligned or winged); shoulder in frontal plane (aligned or imbalance); shoulder in sagittal plane (aligned or protraction); head in frontal plane (aligned or tilt); and head in sagittal plane (aligned or protraction).

Spine flexibility was assessed by Schöber's test ${ }^{14,23}$. For this test, two points were marked: one between the posterior superior iliac spines and the other $10 \mathrm{~cm}$ above the first point. The child then bent the trunk forward, keeping the knees extended. The distance between the two points was measured again after bending the trunk. The value expected in adults is $5 \mathrm{~cm}^{14,23}$.

A symmetrograph ${ }^{\circledast}$ (height: $1.70 \mathrm{~m}$; width: $0.80 \mathrm{~m}$; and squares: $5 \mathrm{~cm}$ ) was used for postural assessment. A digital camera (SONY MVC-FD200/FD Mavica) was positioned at a standardized distance of $2.56 \mathrm{~m}$ from the symmetrograph ${ }^{\circledR}$ and at a height of $0.785 \mathrm{~m}^{17}$. The subjects wore swimwear and/or shorts and shirt and they were positioned immediately in front of the symmetrograph ${ }^{\circledR 17}$.

After the postural assessment, the students with scoliosis (nine girls and thirteen boys) were referred to the physical therapy team. A lecture entitled "Posture Day" for parents, students, and school employees, but primarily directed at teachers, was given to provide information about the problem of inadequate posture.

\section{Statistical analysis}

Firstly, descriptive statistical analysis was performed (percentages, means and standard deviations). For the continuous variables like Schöber's test, the Shapiro-Wilk test was calculated to find whether the behavior of these variables followed normal distribution patterns ( $>0.05$ ). Since the results showed a non-normal distribution, the Mann-Whitney test was used for comparisons between genders.

The characteristics were classified in accordance with nominal and ordinal scales, and were compared using nonparametric tests. For comparison between genders, the MannWhitney test was used. This test compared ordinal variables between pairs of independent samples. Furthermore, the chisquare test was calculated to compare dichotomous variables and to investigate their differences between the genders. The significance level $(\alpha)$ adopted was $5 \%$. Statistica v. 5.1 and Microsoft Excel 2000 v. 7.0 were used for the statistical analysis.

\section{Reliability}

To investigate the intra-rater reliability for each segment analyzed, a single tester assessed the same photos from the whole sample (191 subjects) on two different occasions, one month apart ${ }^{20,24}$. The results from the first measurement were used in the statistical analysis, while the results of the second measurement were used solely to calculate the reliability. The intra-class correlation coefficient (ICC) was applied ${ }^{20,24}$. Values greater than 0.75 were taken to indicate good reliability and values below 0.75 indicated poor to moderate reliability ${ }^{20,24}$.

\section{Results : :}

Some of the segments analyzed presented good reliability, such as the ankle, lumbar spine and scapula (ICC around 0.75). On the other hand, the cervical spine segment presented poor reliability (ICC $=0.43)(\mathrm{p}<0.05)$ (Table 2). 
Table 2. Intra-rater reliability of the analyzed segments.

\begin{tabular}{ccccccccccccc}
\hline Segment & Ankle & ATT* & Knee & Pelvis & $\begin{array}{c}\text { Trunk } \\
\text { sagittal } \\
\text { plane }\end{array}$ & $\begin{array}{c}\text { Trunk } \\
\text { frontal } \\
\text { plane }\end{array}$ & Lumbar & Thoracic & Cervical & Shoulder Scapula & Head \\
\hline ICC $^{* *}$ & 0.86 & 0.68 & 0.66 & 0.59 & 0.64 & 0.67 & 0.78 & 0.68 & 0.43 & 0.58 & 0.74 & 0.55 \\
\hline
\end{tabular}

*ATT=tibiotarsal angle; * ${ }^{* *}$ ICC=intra-rater reliability.

Table 3. Gender comparison of dichotomy variables.

\begin{tabular}{lllcc}
\hline Segment* & Age & p value & Incidence (\%) Boys & Incidence (\%) Girls \\
\hline Scapula & 7 years old & 0.008 & $100 \%$ & $71.8 \%$ \\
\cline { 2 - 5 } & 8 years old & 0.03 & $95 \%$ & $70.96 \%$ \\
\cline { 2 - 5 } & 9 years old & 0.04 & $93.75 \%$ & $66.66 \%$ \\
\hline Shoulder - frontal plane & 9 years old & 0.03 & $87.5 \%$ & $55.55 \%$ \\
\hline Shoulder - sagittal plane & 8 years old & 0.02 & $85 \%$ & $54.83 \%$ \\
\hline Head - frontal plane & 10 years old & 0.03 & $47.6 \%$ & $79.16 \%$ \\
\hline Head - sagittal plane & 8 years old & 0.0 & $80 \%$ & $19.35 \%$ \\
\hline
\end{tabular}

*Segments that presented a statistically significant difference $(p<0.05)$.

Statistically significant differences $(\mathrm{p}<0.05)$ were found between the genders for dichotomous variables such as winged scapula, shoulder (frontal and sagittal planes) and head ( frontal and sagittal planes), as shown in Table 3. For non-dichotomous variables, the boys group was statistically different from the girls group with regard to the cervical spine segment ( $\mathrm{p}=0.04)$. The boys group presented an incidence of cervical hyperlordosis of $50.64 \%$ and cervical rectification of $14.28 \%$, whereas the girls group presented $23.68 \%$ and $19.29 \%$, respectively. Gender results were different for Schöber's test $(\mathrm{p}<0.001)$. The mean \pm standard deviation in Schöber's test was $5.21 \pm 7 \mathrm{~cm}$ for the boys and $7.19 \pm 9 \mathrm{~cm}$ for the girls.

\section{Discussion $: \because$.}

This study qualitatively identified the postural abnormalities that occur most frequently among school children aged seven to ten years and compared the results between boys and girls. The main postural abnormalities found in the children assessed were winged scapula, shoulder and head protraction, shoulder imbalance and cervical hyperlordosis.

There were gender-specific differences in some of the postural abnormalities analyzed. The boys had higher incidences of winged scapula, shoulder imbalance and protraction, head protraction and cervical hyperlordosis than the girls did. Conversely, girls had higher incidences of head tilt and greater Schöber values.

Differences in postural response and orthostatic balance relating to gender, spinal development level, muscle recruitment and skeletal maturity have previously been reported ${ }^{37,8,25}$. Some authors have shown that women have better orthostatic equilibrium than men ${ }^{25}$. According to Grimmer, Williams, Gills, older girls (around 12 years of age) presents a better postural response when carrying loads than does boys and girls aged eight to 11 years.

According to Kendall, McCreary, Provance ${ }^{22}$, winged scapula is common during childhood due to poor scapulothoracic fixation. In the present study, boys showed higher incidence of this abnormality than did girls in the seven to nine-year-old age range. Some authors have reported that girls have a greater layer of adipose tissue under the skin than boys ${ }^{3}$. This factor may have masked the scapula assessment. However, studies on the relation of percentage of fat and observed scapular winging are needed, in order to confirm this assumption. Furthermore, according to Asher ${ }^{3}$, girls reach their maximum muscle strength earlier (at the menarche) than boys (when their height growth has ended). The gain in strength after puberty is greater for boys than for girls ${ }^{26}$. This suggests that scapular fixation occurs in boys at a later age, at the time when the gain in muscle strength is greater.

In our study, we found a high incidence of head protraction in eight-year-old boys. Grimmer et al. ${ }^{8}$ assessed children from 12 to 16 years of age and observed that younger boys had higher craniovertebral angle abnormalities, thus indicating head protraction, when they were subjected to loads (backpacks). Some authors believe that the different postural responses demonstrated by their subjects were related to skeletal maturity, peak height velocity and the weight of the load borne ${ }^{7,813,16}$. Thus, children with more mature skeletons and lower peak height velocity are able to achieve compensatory movements in other parts of the spine (such as the lumbar spine) or in the hip. In the present study, these compensatory movements minimized the abnormalities in the position of the head in relation to the trunk, in contrast to the children with less mature skeletons.

$\mathrm{Pini}^{27}$ stated that high incidence of shoulder protraction is normal during the child development process, and that it starts 
to decrease from ten years of age onwards. Our results showed that this postural abnormality, as was head protraction, was found most frequently in males in the eight-year-old group. The presence of shoulder and head protraction and winged scapula may be associated with thoracic hyperkyphosis ${ }^{15}$. Although our study presented no statistically significant difference for thoracic hyperkyphosis between the genders, higher incidence (more than 20\%) of this postural deviation was shown for boys at all ages. In the literature, there are also studies that observed higher incidence of thoracic hyperkyphosis in men than in women ${ }^{13,28}$.

Another postural abnormality with higher occurrence in men is cervical hyperlordosis. Increased spinal curvature (cervical lordosis and thoracic kyphosis) and head and shoulder protraction can be related to the greater muscle shortening seen in men than in women. Riemann et al. ${ }^{29}$ found greater ankle joint stiffness in men than in women. According to these authors, joint stiffness encompasses contributions from all the structures located within and over the joint (muscles, tendons, skin, subcutaneous tissue, fascia, ligaments, joint capsule and cartilage ${ }^{29}$. Furthermore, this stiffness may be associated with other gender-specific factors such as different concentrations of elastic tissue, flexibility, muscle area and height ${ }^{29}$.

Schöber's test was used to measure lumbar spine flexibility. The normal adult value for this index is $5 \mathrm{~cm}^{23}$. The mean values found for women $(7.19 \pm 9 \mathrm{~cm})$ and men $(5.21 \pm 7 \mathrm{~cm})$ in our study were greater than the normal adult value. No Schöber's index values for children exist in the literature. However, in a report on the extreme lumbar flexibility of small children (four to ten years of age), Kendall , McCreary, Provance ${ }^{22}$ asserted that this behavior is modified from 11 years of age onwards, when the legs become proportionally longer than the trunk.

Girls showed greater mean Schöber's indices than boys. This might indicate the presence of greater muscle shortening in males, and greater flexibility in girls. Perret et al. ${ }^{14}$ found greater values for men than for women (average age of 42 years) in fingertip-to-floor tests, which indicate greater flexibility for women than for men.
Shoulder imbalance was most frequently observed in the nine-year-old boys. The factors influencing the assessment of this variable, such as trapezius muscle mass, may have caused some errors in this assessment ${ }^{17}$. Some studies have shown that postural abnormalities such as shoulder imbalance are predictive of the development of scoliosis, while other abnormalities such as shoulder and head protraction may indicate thoracic hyperkyphosis ${ }^{30}$. Both scoliosis and thoracic hyperkyphosis tend to become more evident during the growth spurt ${ }^{3}$.

Analysis of the ankle, lumbar and scapular segments presented good reliability, but the analysis of the other segments presented only poor to moderate reliability. The reliability could be improved by quantitative postural assessment using the same photographs ${ }^{24}$. However, the results of the measures of low reliability should be taken with caution. Despite this limitation, the present study demonstrated that gender differences in posture exist in children well before the onset of puberty. Further studies are needed in order to better explain why these differences occur.

\section{Conclusions $::$.}

There were differences between the genders for some of the postural variables analyzed. Greater incidence of winged scapula, shoulder imbalance and protraction, head protraction and cervical hyperlordosis was shown for boys, and higher incidence of head tilt and greater Schöber's index values was shown for girls. This results demonstrate that, during children's postural development, there are gender-specific abnormalities, which may be related to muscle, skeletal and flexibility differences that can influence the postural patterns of the individual during growth.

There are only a few studies in the literature that investigated the postural patterns of school-age children and the gender differences in posture ${ }^{3,7,8,13,15,17,21}$. Longitudinal studies that analyze children's posture quantitatively are needed in order to better explain how gender differences in development can influence the formation of adult postural patterns. 


\section{References $: \because$.}

1. Gangnet N, Pomero V, Dumas R, Skalli W, Vital JM. Variability of the spine and pelvis location with respect to the gravity line: a three-dimensional stereoradiographic study using a force platform. Surg Radiol Anat. 2003;25(5-6):424-33.

2. Shumway-Cook A, Woollacott MH. Motor control: theory and practical applications. Maryland (USA): Lippincott Williams and Wilkins; 2001.

3. Asher C. Variações de postura na criança. São Paulo: Manole; 1976.

4. Westcott SL, Lowes LP, Richardson PK. Evaluation of postural stability in children: current theories and assessment tools. Phys Ther. 1997;77(6):629-45.

5. Griegel-Morris P, Larson K, Mueller-Klaus K, Oatis CA. Incidence of common postural abnormalities in the cervical, shoulder, and thoracic regions and their association with pain in two age groups of healthy subjects. Phys Ther. 1992;72(6):425-31.

6. Szeto GP, Straker L, Raine S. A field comparison of neck and shoulder postures in symptomatic and asymptomatic office workers. Appl Ergon. 2002;33(1):75-84

7. Chansirinukor W, Wilson D, Grimmer K, Dansie B. Effects of backpacks on students: measurement of cervical and shoulder posture. Aust $J$ Physiother. 2001;47(2):110-6.

8. Grimmer KA, Williams MT, Gill TK. The associations between adolescent head-on-neck posture, backpack weight, and antropometric features. Spine. 1999;24(21):2262-7.

9. Mackenzie WG, Sampath JS, Kruse RW, Sheir-Neiss GJ. Backpacks in children. Clin Orthop Relat Res. 2003;409:78-84.

10. Sheir-Neiss GI, Kruse RW, Rahman T, Jacobson LP, Pelli JA. The association of backpack use and backpack pain in adolescents. Spine. 2003;28(9):922-30.

11. Mikkelsson M, Salminen JJ, Sourander A, Kautiainen H. Contributing factors to the persistence of musculoskeletal pain in preadolescents: a prospective 1-year follow-up study. Pain. 1998;77(1):67-72.

12. Niemi S, Levoska S, Kemilä J, Rekola K, Keinänen-Kiukaanniemi S. Neck and shoulder symptoms and leisure time activities in high school students. J Orthop Sports Phys Ther. 1996;24(1):25-9.

13. Widhe T. Spine: posture, mobility and pain. A longitudinal study from childhood to adolescence. Eur Spine J. 2001;10(2):118-23.

14. Perret C, Poiraudeau S, Fermanian J, Colau MM, Benhamou MA, Revel M. Validity, reability, and responsiveness of the fingertip-to-floor test. Arch Phys Med Rehabil. 2001;82(11):1566-70.
15. Brighetti V, Bankoff ADP. Levantamento da incidência de cifose postural e ombros caídos em alunos de $1^{\mathrm{a}}$ à $4^{\mathrm{a}}$ séries escolares. Rev Bras Cienc Esporte. 1986;7(3):93-7.

16. Pascoe DD, Pascoe DE, Wang YT, Shim DM, Kim CK. Influence of carring book bags on gait cycle and posture of youths. Ergonomics. 1997;40(6):631-41.

17. Penha PJ, João SM, Casarotto RA, Amino CJ, Penteado DC. Postura assessment of girls between 7 and 10 years of age. Clinics. 2005;60(1):9-16.

18. Arnheim DD, Auxter D, Crowe WG. Principles and methods of adapted physical education and recreation. St Louis: CV. Mosby Company; 1977.

19. Watson AW, Mac Donncha C. A reliable technique for the assessment of posture: assessment criteria for aspects of posture. J Sports Med Phys Fitness. 2000;40(3):260-70.

20. GadottilC,VieiraER, MageeDJ. Importanceand clarification ofmeasurement properties in rehabilitation. Rev Bras Fisioter. 2006;10(2):137-46.

21. Harrison AL, Barry-Greb T, Wojtowicz G. Clinical measurement of head and shoulder posture variables. J Orthop Sports Phys Ther. 1996;23(6):353-61.

22. Kendall FP, McCreary EK, Provance PG. Músculos provas e funções. $4^{\mathrm{a}}$ ed. São Paulo: Manole; 1995.

23. Marques AP. Manual de Goniometria. São Paulo: Manole; 2003.

24. Iunes DH, Castro FA, Salgado HS, Moura IC, Oliveira AS, Bevilaqua-Grossi D. Confiabilidade intra e interexaminadores e repetibilidade da avaliação postural pela fotogrametria. Rev Bras Fisioter. 2005;9(3):327-34.

25. Mouzat A, Dabonneville M, Bertrand P. The effect of feet position on orthostatic posture in a female sample group. Neurosci Lett. 2004;365(2):79-82.

26. Buchanan PA, Vardaxis VG. Sex-related and age-related differences in knee strength of basketball players ages 11-17 years. J Athl Train. 2003;38(3):231-7.

27. Pini MC. Fisiologia Esportiva. Rio de Janeiro: Guanabara Koogan; 1978.

28. Mellin G, Poussa M. Spinal mobility and posture in 8- to 16-year-old children. J Orthop Res. 1992;10(2):211-6.

29. Riemann BL, DeMont RG, Ryu K, Lephart SM. The effects of sex, joint angle, and the gastrocnemius muscle on passive ankle joint complex stiffness. J Athl Train. 2001;36(4):369-77.

30. Juskeliene V, Magnus P, Bakketeig LS, Dailidiene N, Jurkuvenas V. Prevalence and risk factors for asymmetric posture in preschool children aged 6-7 years. Int J Epidemiol. 1996;25(5):1053-9. 